\title{
Faith and Freedom: Leukemia in Jehovah Witness Minors
}

\author{
R.T. Penson P.C. Amrein \\ Department of Medicine, Division of Hematology-Oncology, Massachusetts General Hospital, Boston, USA
}

In this issue of ONKOLOGIE Tenenbaum et al., report their experience of managing pediatric cancer patients belonging to Jehovah's Witness families [1]. Perhaps the most remarkable element of Tenenbaum's paper is that they succeeded in a 'continuous collaboration with the Hospital Committee for Jehovah's Witnesses', a recourse potentially as important as seeking overrule by the courts. Using proactive oral or written clarification of the legal mandate to transfuse, in emergency situations, transfusions in these institutions are now given without signed parental consent or a court order.

The state's right to interfere with the parents' right to decide for their children has changed over the centuries: English royalty originally had virtually unlimited power over the minors of their subjects. Over time, the Crown's power became circumscribed by the rule of law, through the Magna Carta, the Writ of Habeas Corpus, and the continual evolution of the common law. In 1776, the great experiment in freedom, 'The United States of America', started government 'of the people, by the people, for the people.' Some scholars believe the freedom ended before the ink was dry on the constitution. Positively the government could become the trustee of a child, and negatively, it is claimed, Parens Patriae power has been invoked unjustly to over-rule a parent's custodial rights.

In 1839 a Pennsylvania court ruling upheld a mother's decision to have her daughter committed to an institution, despite the father's petition for her release [2]. A series of similar cases codified this decision and in 1991 the Supreme Judicial Court of Massachusetts supported a local court's decision to permit administration of blood transfusions to eight-year-old Elisha McCauley, as part of treatment of leukemia. The court found that, while the private realm of family life must be protected from unwarranted state interference, when a child's life was at stake, the child's welfare, and not the parents' rights, were the paramount consideration. An earlier test of religious freedom came to the same conclusion, with the court ruling that 'Parents may be free to become martyrs themselves. But it does not follow that they are free, in identical circumstances, to make martyrs of their children before they have reached the age of full and legal discretion when they can make that choice for themselves' [3].

There are nearly one million Jehovah's Witnesses in the United States and more than five million worldwide [4]. Founded in 1870, the group took the name 'Jehovah's Witnesses' in 1931 [5]. In 1945, the Watchtower Bible and Tract Society (WBTS), the overseeing body of Jehovah's Witnesses, determined that accepting blood and blood products for medical purposes directly violated the teachings of the Bible. This determination focused primarily on three Bible passages (Genesis 9:3-4; Leviticus 17:10-14; and Acts 15:21-29), which forbid the ingestion of blood [4-6]. Relying on literal interpretations of the Bible, Jehovah's Witnesses believe that this prohibition applies at all times, even in emergency situations, and that there is no distinction between ingesting blood orally versus intravenously [6]. Since 1945 the WBTS has categorically disparaged accepting blood transfusions as a sacrilegious act [7]. Notwithstanding this dogmatic teaching an analysis shows that not all Jehovah's Witnesses agreed with this position. In the 1950s the WBTS admitted it had received repeated requests from some of its adherents seeking that the medical practice of blood transfusion therapy should be accepted [7]. In 1958 WBTS literature admits some its adherents were conscientiously accepting blood transfusion therapy [8]. Since 1961 the WBTS has published a policy whereby Jehovah's Witnesses must shun fellow believers who conscientiously accepted a blood transfusion. Furthermore, on a website on Jehovah's Witnesses there is a remarkable dialogue between an active elder in the United States and the Governing Body of Jehovah's Witnesses about the subject of blood transfusion, claiming that '[a] deaf ear [is] turned to so many' [9], showing that the issue is controversial also among the leaders.

The now famous quote by Art Spander, the sports columnist for the San Francisco Examiner, 'The great thing about democracy is that it gives every voter a chance to do something stupid', frames the prejudice inherent in the difficult is-

\begin{tabular}{ll}
\hline KARGER & ๑ 2004 S. Karger GmbH, Freiburg \\
Fax +497614520714 & Accessible online at: \\
$\begin{array}{l}\text { E-mail Information@Karger.de } \\
\text { www.karger.com }\end{array}$ & www.karger.com/onk
\end{tabular}

Richard T. Penson, M.R.C.P., M.D.

Instructor in Medicine, Hematology-Oncology

Cox 548, 100 Blossom St

Boston, MA 02114-2617, USA

Tel. +1 617 72-6 5867, Fax -4 6898

E-Mail rpenson@partners.org 
sues of rule and respect. Brock and Wartman very helpfully crystallized the debate, separating irrational choices (which the physician may seek to change) from 'unusual' choices, which should be respected [10]. For older minors legal competence is determined by their ability to understand the pros and cons of a treatment, the other options and their implications, and to weigh the decision. In the US even irrational choices of a competent patient must be respected if the patient cannot be persuaded to change them. In 2000, the WBTS slightly altered its policy on blood. It discontinued the process of 'disfellowshipping' unrepentant Jehovah's Witnesses who had accepted blood, a procedure during which a judicial committee determined whether or not a congregation member had knowingly accepted a blood product. Now, the acceptance of blood is instead considered a personal act of 'disassociation'. This alteration does not affect the prohibition of blood products; it only centers a person's removal from the faith on an individual action instead of on a judicial committee's determination [11]. As medical treatments have grown more complicated, so has the WBTS's regulation of blood products. The WBTS specifically prohibits whole blood, red blood cells, white blood cells, plasma, and platelets in addition to preoperative banking of one's own blood. Other components such as albumin, fibrin, bone marrow, stem cells, dextrans, and oxygen carrying blood substitutes are more acceptable. The WBTS leaves decisions about accepting these components to the discretion of individual conscience $[4,12]$. While one Jehovah's Witness may accept all blood products except for whole blood, another may refuse all blood products, transfusion techniques, and agents to increase blood counts. Because of such complexities and variations, caregivers need to discuss these issues with each Jehovah's Witness patient in order to understand which blood products, if any, the patient feels are acceptable [5].

Several new procedures have emerged to address the medical needs of Jehovah's Witnesses. Some hospitals have initiated 'bloodless surgery' programs, which rely on several techniques to reduce blood loss during surgery [5]. One technique, cellsaver autotransfusion, involves salvaging lost blood from the surgical field, cleaning it, and returning it to the patient. During the procedure, the blood remains in a constant circuit with the body, so many Jehovah's Witnesses accept this technique $[5,11,12]$. Other techniques to address blood loss include hormonal suppression of menstrual cycles, limited phlebotomy, and stimulation of blood component production by agents such as erythropoietin [13], and use of bovine hemoglobin [14]. While treating any patient with acute leukemia involves a balance between treating the disease and avoiding treatment toxicity, this balance becomes much more tenuous for patients who refuse blood products. Recent case studies report success in treating Jehovah's Witness leukemia patients [15-17]. Alltrans retinoic acid (ATRA) combined with arsenic trioxide has been used with minimal hematological toxicity for patients with acute promyelocytic leukemia (APML), however, only $10 \%$ of adults with acute myeloid leukemia have this FAB subtype [16].

Consistently, courts have upheld the rights of competent adults to refuse lifesaving treatment [18-20]. The 1976 case of Karen Quinlan was pivotal in addressing the issue of care refusal. At the time of the case, Quinlan had been in a vegetative state since 1975, and her father wished to withdraw artificial ventilation. Convinced by the evidence presented that Quinlan herself would have chosen to discontinue treatment, the United States Supreme Court ruled in favor of withdrawing ventilatory support [21]. The 1990 case of Nancy Cruzan further addressed the issue of surrogate care refusal on behalf of an incompetent adult. As a result of severe head injuries following a car accident, Cruzan was in a persistent vegetative state with no signs of significant cognitive function. Cruzan's parents petitioned the court to discontinue the artificial nutrition and hydration that were keeping Cruzan alive because they felt that Cruzan would not have wanted to live under such circumstances. Cruzan's case differed from Quinlan's because the evidence regarding Cruzan's wishes was less convincing. Here, the Supreme Court ruled that a state is not required to enforce a surrogate decision-maker's refusal of treatment on behalf of an incompetent adult unless there is 'clear and convincing evidence' of the patient's wishes [22]. Courts have also specifically upheld the rights of adult Jehovah's Witnesses to refuse lifesaving blood transfusions [23]. However, a patient's right to refuse lifesaving treatment has been legally challenged when the person refusing blood is pregnant or will be abandoning his or her children by dying [4, 23].

Conflicts emerge when patients refuse lifesaving treatment. If a patient's belief system fundamentally clashes with those of caregivers, it challenges the boundaries of what is ethical, compassionate, and acceptable. While balancing beneficence and nonmaleficence, the most good for the least harm, caregivers must also respect autonomy and justice. Physicians rightly question their own decisions and actions [24], but the unexamined life is not worth living [25]. We have an equally important responsibility to be aware of and explore the values of our patients.

\section{References}

1 Tenenbaum T, Hasan C, Kramm, C, Janßen G, Laws HJ, Wessalowski R, Bode U, Göbel U: Oncological management of pediatric cancer patients belonging to Jehovah's Wittnesses' a two-institutional experience report. Onkologie 2004;27:131-137.
2 Chesler P: Mothers on Trial: The battle for children and custody. New York, NY, McGraw-Hill, 1986.

3 Prince vs. Massachusetts 321 US 158.

4 Robinson M, Carvalho M, Rundle A: Honoring Patient Preferences: A Guide to Complying with Multicultural Patient Requirements. San Francisco, CA, Jossey-Bass, 1999.
5 deCastro RM: Bloodless surgery: Establishment of a program for the special medical needs of the Jehovah's witness community - the gynecologic surgery experience at a community hospital. Am J Obstet Gynecol 1999;180:1491-1498. 
6 Watch Tower Bible and Tract Society of Pennsylvania: Jehovah's Witnesses and the Question of Blood. New York, NY, Watchtower Bible and Tract Society of New York, 1977.

7 Anonymous: Further on blood transfusion. The Watchtower 1950:143.

8 Anonymous: Watch Tower Bible and Tract Society of Pennsylvania, questions from readers. The Watchtower 1958:478.

9 http://watchtower.observer.org/apps/pbcs.dll/artikkel? SearchID $=73155160881245 \&$ Avis $=$ WO \&Dato $=200$ $30801 \&$ Kategori $=J W A N D M E D I C I N E 2 \&$ Lopenr $=$ $201220009 \&$ Ref $=A R$.

10 Brock DW, Wartman SA: When competent patients make irrational choices. N Engl J Med 1990; 322:1595-1599.

11 Muramoto O: Bioethical aspects of the recent changes in the policy of refusal of blood by Jehovah's witnesses. BMJ 2001;322:37-39.
12 Dasen KR, Niswander DG, Schlenker RE: Autologous and allogenic blood products for unanticipated massive blood loss in a Jehovah's Witness. Anesth Analg 2000;90:553-555.

13 Cothren C, Moore EE, Offner PJ, Haenel JB, Johnson JL: Blood substitute and erythropoietin therapy in a severely injured Jehovah's witness. N Engl J Med 2002;346:1097-1098.

14 Knuti KA, Amrein PC, Chabner BA, Lynch TJ Jr., Penson RT: Faith, identity, and leukemia: When blood products are not an option. Oncologist 2002; 7:371-380

15 Cullis JO, Duncombe AS, Dudley JM, Lumley HS Apperley JF, Smith AG: Acute leukaemia in Jehovah's Witnesses. Br J Haematol 1998;100:664-668.

16 Kennedy GA, Marlton P, Cobcroft R, Gill D: Molecular remission without blood product support using all-trans retinoic acid (ATRA) induction and combined arsenic trioxide/ATRA consolidation in a Jehovah's Witness with de novo acute promyelocytic leukaemia. Br J Haematol 2000;111:11031105 .
17 Kerridge I, Lowe M, Seldon M, Enno A, Deveridge $\mathrm{S}$ : Clinical and ethical issues in the treatment of a Jehovah's Witness with acute myeloblastic leukemia. Arch Intern Med 1997;157:1753-1757.

18 Tune vs. Walter Reed Army Medical Hospital FSU, 1985

19 Georgia vs. McAfee GSNSA, 1989.

20 McKay vs. Bergstedt NSN, 1990.

21 In re Quinlan AdN, 1976.

22 Cruzan vs. Director MDoH, 497 US 261, 1990.

23 Norwood Hospital vs. Munoz NEdM, 1991.

24 Stotland NL: When religion collides with medicine. Am J Psychiatry 1999;156:304-307.

25 Plato: Apology of Socrates; in West T, West G (eds): Four Texts on Socrates. Ithaca, NY, Cornel University Press, 1998, p 92. 